Published in: Rushton, A.W.A., Brück, P.M., Molyneux, S.G., Williams, M. \& Woodcock, N.H. 2011. A Revised Correlation of the Cambrian Rocks in the British Isles. Geological Society, London, Special Report 25, 21-27.

\title{
10. Scotland: Hebridean Terrane
}

\section{A. W. A. RUSHTON. \& S. G. MOLYNEUX}

The Cambrian succession in the Hebridean Terrane extends for about $200 \mathrm{~km}$ from near Durness on the northern coast of the Scottish mainland SSW to Skye (Fig. 14). The classic account of the whole region is the memoir by Peach et al. (1907), which work had a great influence on British geological studies in the Lower Palaeozoic during the earlier part of the $20^{\text {th }}$ century. The geology of the region was described by Park et al. (2002) and some critical localities were reviewed by Prigmore \& Rushton (1999). Sedimentological studies by Swett and his collaborators (Swett \& Smit 1972) and by McKie (1990a-c, 1993) and new litho- and biostratigraphical work, including the study of microfossil faunas and floras, have led to a re-appraisal of the stratigraphical succession and its correlation.

The Cambrian succession (column 22, Fig. 15) consists of a generally upwardfining sequence of clastic deposits, the Ardvreck Group of early Cambrian age, followed by a succession of carbonate formations, the Durness Group, of Cambrian to early Ordovician age. The strata were deposited on a stable, gently sloping shelf, and because the facies represented are generally similar throughout the length of the outcrop, it is inferred that the trend of the shelf lay approximately parallel to the line of the present outcrop (Bluck 2007).

The characteristics of the rocks, and especially of the faunas, have long led to comparison of the Cambrian-Ordovician succession of north-western Scotland with rocks of the same age in North America, whereas the strongly provincial character of the faunas hinders precise correlation with the Avalonian standard. The presence of the typically Laurentian trilobite genus Olenellus and the tubular organism Salterella allow reference of the Ardvreck Group to the later parts of the early Cambrian (upper part of Series 2?) whilst the shelly, mainly molluscan, fossils from the formations of the upper parts of Durness Group are comparable with those from the zones of the Ibexian Series of the North American Ordovician, which are approximately equivalent to the Tremadoc and Arenig series of traditional British usage. Nicholas (1994) and Wright \& Knight (1995) proposed a revised correlation of the Durness 
Group, whilst Huselbee \& Thomas (1998) discussed the biostratigraphy of the succession.

The lower member of the transgressive Eriboll Formation, the Basal (or False Bedded) Quartzite, is unfossiliferous, except for acritarch assemblages recovered from fine-grained lithologies near Ullapool (Molyneux 2006). The acritarchs comprise almost monospecific assemblages of leiospheres (sphaeromorph acritarchs), accompanied by rare and indeterminate acanthomorph acritarchs in one sample. Such low-diversity assemblages provide no evidence for age, but are suggestive of shallow marine environments, consistent with the transgressive nature of the deposit. The overlying Pipe Rock Member contains abundant burrows of the trace-fossil Skolithos, which is characteristic of post-Neoproterozoic rocks. Peach et al. (1907, p. 373) recorded the early Cambrian tubular fossil Salterella maccullochii in the upper part of this member. The age of the An t-Sròn Formation is more closely constrained by the trilobites and acritarchs recorded from the Fucoid Beds Member. The trilobites are olenellid species, referable to subgenera well known from the Laurentian parts of North America: Olenellus (Mesonacis) reticulatus, O. (Paedumias) lapworthi, with O. (Angustolenellus) hamoculus and Olenelloides armatus locally. Palmer \& Repina (1993) assigned this fauna to the mid-part of the Olenellus Trilobite Zone of the North American standard, which lies somewhat below the higher of the prospective levels at which the boundary between Series 2 and Series 3 is expected to be defined (Geyer 2005, p. 94). Acritarch floras from the Fucoid Beds Member at Knockan, Skiag Bridge and Ullapool, described by Downie (1982; see also Molyneux 2006), include Asteridium spinosum, Cymatiosphaera postae, Globosphaeridium cerinum, Goniosphaeridium implicatum, Goniosphaeridium varium, Multiplicisphaeridium dendroideum, Revinotesta ordensis, Skiagia brevispinosa, Skiagia ciliosa, Skiagia orbicularis and Skiagia ornata, which taken together indicate the dissimilare-ciliosa Acritarch Zone. The first appearance datum (FAD) of Volkovia dentifera towards the top of the Fucoid Beds Member at Knockan suggests that the top of the member is in the overlying dentifera-plana Acriarch Zone. The acritarchs from the upper part of the Fucoid Beds therefore suggest a level in the upper part of the dissimilare-ciliosa Biozone or lower part of the dentifera-plana Biozone (Series 2, Stage 4), which in turn suggests correlation with the middle part of the Bonnia-Olenellus Trilobite Zone of North America (Fig. 3), and is consistent with the trilobite evidence. The Salterella 
Grit Member is named after the abundance of Salterella, but has also yielded $O$. (P.) lapworthi (Peach et al. 1907, p. 375).

The lowest division of the overlying Durness Group is the Ghrudaidh Formation, which includes Salterella in its lowest part. Huselbee \& Thomas (1998) collected an example of Olenellus aff. reticulatus from the basal Ghrudaidh Formation in a thrust slice near Inchnadamph, Assynt, confirming that the lowest part of the Durness Group lies within the Olenellus Biozone. Higher levels in the Ghrudaidh Formation lack fossils.

Huselbee \& Thomas (1998, pp. 86-87) demonstrated that the topmost part of the succeeding Eilean Dubh Formation is of earliest Ordovician age, as shown by the occurrence of conodonts, especially the short-ranging species Cordylodus lindstromi. Below this the Eilean Dubh Formation has yielded fossils, though nothing stratigraphically very reliable (Huselbee \& Thomas 1998). However, Wright \& Knight (1995) made detailed comparisons between the Ghrudaidh and Eilean Dubh formations of Scotland and the Port au Port Group in the northern part of western Newfoundland, and they found sufficient similarities in lithostratigraphy and sedimentary facies to propose a direct correlation. As there is a measure of biostratigraphical control throughout the Port au Port Group, it is accepted that the Ghrudaidh Formation extends through much of Series 3 (“Middle Cambrian”) and the Eilean Dubh Formation extends through the whole of the Furongian ("Upper Cambrian”). Figure 15 shows this correlation set alongside stratigraphical subdivisions of the Laurentian Cambrian. The divisions Waucoban to Canadian are shown because they were commonly used through much of the $20^{\text {th }}$ century and appear in the older literature. However, the more recently proposed divisions from Montezuman to Ibexan are rigorously defined and can be more reliably aligned with the proposed international standard. 


\section{REFERENCES}

BLUCK, B. J. 2007. Anomalies on the Cambrian-Ordovician passive margin of Scotland. Proceedings of the Geologists' Association, 118, 55-62.

DownIE, C. 1982. Lower Cambrian acritarchs from Scotland, Norway, Greenland and Canada. Transactions of the Royal Society of Edinburgh, Earth Sciences, 72, 257-285.

GeYer, G. 2005. The base of a revised Middle Cambrian: are suitable concepts for a series boundary in reach? Geosciences Journal, 9, 81-99.

Huselbee, M. Y., \& ThOmas, A. T. 1998. Olenellus and conodonts from the Durness Group, NW Scotland, and the correlation of the Durness succession. Scottish Journal of Geology, 34, 83-88.

MCKIE, T. 1990a. A model for marine shelf storm deposition in the Lower Cambrian Fucoid Beds of northwest Scotland. Geological Magazine, 127, 45-53.

MCKIE, T. 1990b. Tidal and storm-influenced sedimentation from a Cambrian transgressive passive margin sequence. Journal of the Geological Society, London, 147, 785-794.

McKIE, T. 1990c. Tidal sandbank evolution in the Lower Cambrian Salterella Grit. Scottish Journal of Geology, 26, 77-88.

MCKIE, T. 1993. Relative sea-level changes and the development of a Cambrian transgression. Geological Magazine, 130, 245-256.

MolyneUX, S. G. 2006. A palynological investigation of samples from the Lower Cambrian, NW Highlands, Scotland. British Geological Survey Internal Report, IR/06/134, 22 pp.

NicholAs, C. J. 1994. New stratigraphical constraints on the Durness Group of NW Scotland. Scottish Journal of Geology, 30, 73-85.

PAlmeR, A. R. \& RePinA, L. N. 1993. Through a glass darkly: taxonomy, phylogeny, and biostratigraphy of the Olenellina. The University of Kansas, Paleontological Contributions, New series, no. 3, 1-35.

Park, R. G., Stewart, A. D. \& Wright, D. T. 2002. The Hebridean terrane. In: Trewin, N. H. (ed) The geology of Scotland, 4th edition. Geological Society, London, 45-80.

Peach, B. N., Horne, J., Gunn, W., Clough, C. T., Hinxman, L. W. \& Teall, J. J. H. 1907. The geological structure of the north-west Highlands of Scotland. Memoir of the Geological Survey of Great Britain. xviii + 668 pp., 52 pls, map. H.M.S.O. 
PrigmoRe, J. K. \& Rushton, A. W. A. 1999. Scotland: Cambrian and Ordovician of the Hebridean terrane. In: Rushton, A. W. A., Owen, A. W., Owens, R. M. \& PRIGMORE, J. K. British Cambrian to Ordovician stratigraphy. Geological Conservation Review Series 18. Joint Nature Conservation Committee, Peterborough, 293-315.

SwETT, K. \& SMIT, D. E. 1972. Paleogeography and depositional environments of the Cambro-Ordovician shallow-marine facies of the North Atlantic. Geological Society of America Bulletin, 83, 3223-3248.

TAnner, P. W. G., \& Sutherland, S. 2007. The Highland Border Complex, Scotland; a paradox resolved. Journal of the Geological Society, London, 164, 111-116.

WRight, D. T., \& KNIGHT, I. 1995. A revised chronostratigraphy for the lower Durness Group. Scottish Journal of Geology, 31, 11-22. 
Cambrian Correlation Report - Figures

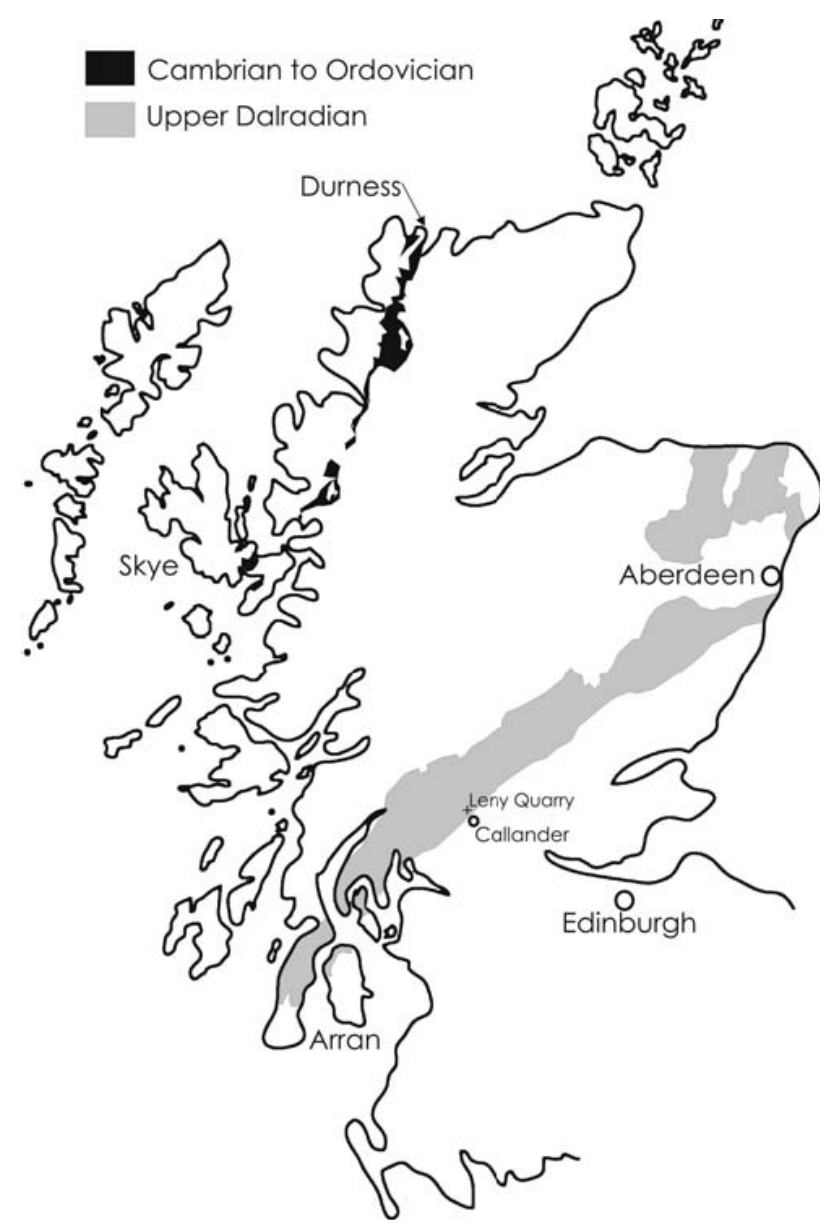

Fig. 14. Distribution of Cambrian to early Ordovician rocks and the Upper Dalradian Supergroup (Neoproterozoic to Cambro-Ordovician) in Scotland. 


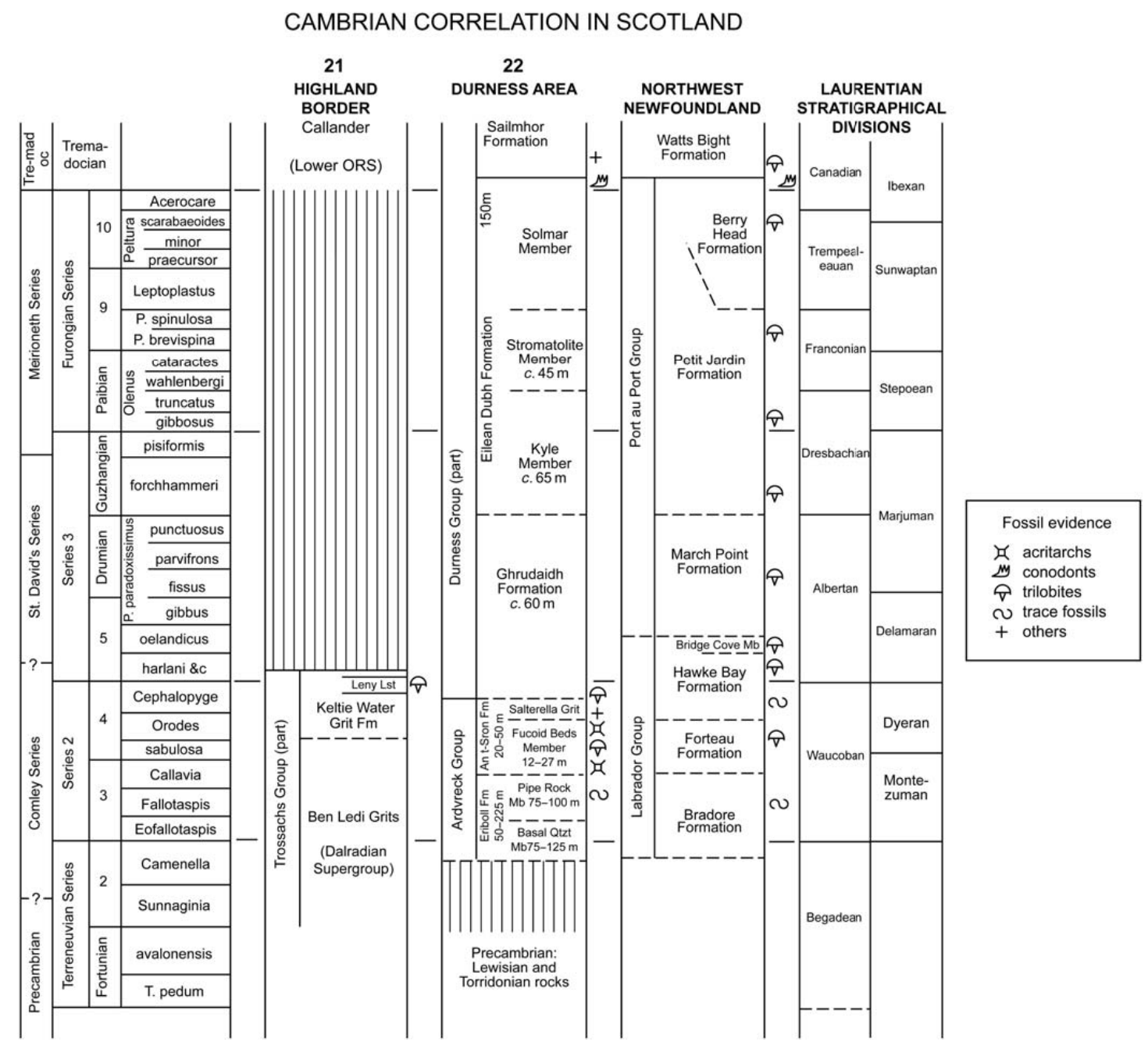

Fig. 15. Correlation of Cambrian rocks in Scotland. Column 21 shows the Trossachs Group of Tanner \& Sutherland (2007) as the upper Dalradian on the southeast edge of the Central Highlands Terrane. Column 22 shows the succession in the Northwest Highlands (Hebridean Terrane), and its correlation to the succession in northwest Newfoundland (Wright \& Knight 1995) and the Laurentian standard. 